\title{
Skill and Expertise in Three Schools of Classical Chinese Thought ${ }^{*}$
}

\author{
Hagop Sarkissian \\ The City University of New York \\ Graduate Center | Baruch College
}

\begin{abstract}
The classical Chinese philosophical tradition (ca. 6th to 3rd centuries BCE) contains rich discussion of skill and expertise. Various texts exalt skilled exemplars (whether historical persons or fictional figures) who guide and inspire those seeking virtuosity within a particular dao (guiding teaching or way of life). These texts share a preoccupation with flourishing, or uncovering and articulating the constituents of an exemplary life. Some core features thought requisite to leading such a life included spontaneity, naturalness, and effortless ease. However, there was also significant disagreement during this 'Warring States' or 'Hundred Schools' period on which skills were valuable, how one should cultivate them, and who exactly ought to serve as exemplars. In this chapter, I discuss two prominent types of expertise and their attendant skills. The first is expertise at a particular craft, occupation, or dao, which finds its most poignant celebration in the early Daoist anthology Zhuangzi. Interest in crafts or skilled occupations was likely motivated by a perceived (or implied) analogy with living a good life more generally. The second concerns ethical expertise, a prominent and widely held ideal within the Ruist (Confucian) and Mohist schools. Both maintain that ethical expertise consists of an ability to apply past models or precedents to current cases, though they diverge on what those models are and how to properly apply them. The aim is to provide nonspecialists an overview of this literature in Daoism, Confucianism, and Mohism, while also providing suggestions about further research.
\end{abstract}

\footnotetext{
* Penultimate draft. Forthcoming in The Routledge Handbook of Skill and Expertise, edited by Ellen Fridland and Carlotta Pavese. Please refer to and cite the published version.
} 


\title{
Skill and Expertise in Three Schools of Classical Chinese Thought
}

\author{
Hagop Sarkissian \\ The City University of New York \\ Graduate Center | Baruch College
}

When reading texts in the classical Chinese philosophical tradition (ca. 6th to 3rd centuries $B C E)$, one is struck by regular celebrations of skill and expertise. Various schools of thought exalt skilled exemplars (whether historical persons or fictional figures) for guiding and inspiring those seeking virtuosity within particular daos (guiding teachings or ways of life), reflecting a shared preoccupation with uncovering and articulating the constituents of an exemplary life. Indeed, there is substantial overlap on some of the core features thought requisite to leading such a life, including spontaneity, naturalness, and effortlessness (e.g. Slingerland, 2007). Nonetheless, given the wide array of philosophical thought in this period (later dubbed the Hundred Schools period), there was also significant disagreement on what skills were valuable, how one should cultivate them, and who exactly ought to serve as exemplars.

In what follows, I will discuss two prominent types of expertise and their attendant skills. The first is expertise at a particular craft, occupation, or dao, which finds its most poignant celebration in the early Daoist anthology Zhuangzi. Interest in crafts or skilled occupations was likely motivated by a perceived (or implied) analogy with living a good life more generally. The second is ethical expertise, a prominent and widely held ideal within the Ruist (Confucian) and Mohist schools. Both maintain that ethical expertise consists of an ability to apply past models or precedents to current cases, though they diverge on what those models are and how to properly apply them. The aim is to provide non-specialists an overview of this literature as well as suggestions about further research.

\section{Skill in Craft and Performance}

Some of the most well-known examples of skill and expertise involve particular crafts, professions, or ways of life. Chapter 19 ("Probing Life" 達生) of the Zhuangzi, a compendium of early Daoist thought, contains many such examples. The accounts share a common structure: a member of the societal elite (e.g. a Duke or Marquis) or a moralizing philosopher (e.g. Kongzi, better known to Westerners as Confucius) encounters a person of lower social status engaged in a mundane activity, yet with such depth of skill, grace, and proficiency, that it startles him. A lesson is thereby seemingly imparted about realms of meaningful human experience that are 
typically overlooked. Thus, these episodes both valorize skill while also denigrating the blinkered perspective of the elite.

For example, in a representative passage, Kongzi gazes at a waterfall producing rapids so turbulent that no sea creatures dare swim in it, and foam so abundant that it persists miles downstream. Suddenly, he catches sight of a solitary figure in the water. Thinking this person in mortal danger he dispatches a disciple to render aid, only to see the person emerge from the depths full of song. Amazed, Kongzi asks for his dao of swimming. Instead, the swimmer describes his skill as developing naturally out of his having grown up both on land and in water, and thus being adept and at ease in both environments. These were the original circumstances given to him (gu 故), and his life course developed naturally therein. He cannot further articulate or illuminate his skiil save for thin descriptions (e.g. 'following the current'). What was ordinary from his perspective resulted in a way of life seemingly extraordinary to others. Here, Kongzi represents the perspective of a judgmental elite, who claims to possess deep insight on what is proper and improper, admirable and inadmirable, and goes around promulgating his beliefs on the assumption that people require guidance and education. Kongzi assumes the swimmer needs his help, yet he requires none at all. Rather, he has a surety and ease with his own life that Kongzi seems to lack (e.g. Møllgaard, 2007, p. 61). The nameless swimmer is thus a foil to the famous sage, who is characterized as out of touch and out of his depths.

The story of Wheelwright Pian in the same chapter follows this pattern of depicting skill as something learned through practice and hard to convey with words. "Neither slow nor hurried, I feel it through my hand, and it resonates with my mind," explains the wheelwright. "My mouth cannot put it into words. There is a knack in it somewhere that I cannot convey to my son, and which he cannot learn from me" (13/37/16-18). ${ }^{1}$ Here's the general lesson:

Everyone in the world values dao when found in texts. A text does not go beyond its sayings, yet the sayings contain something of value. What is of value in sayings is the impressions they convey. The impressions follow from something else, and these cannot be transmitted with words. Alas, everyone values mere sayings and so transmits texts. Even though everyone values them [i.e. words and books], to me they seem not to obtain value; what everyone values is not what's really of value. $(13 / 37 / 5-6)$

\footnotetext{
${ }^{1}$ Translations of the Zhuangzi are my own, though I consulted Graham (2001) and Ziporyn (2009). The numbering of sections (Book/Page/Line) refers to the standard ICS concordance. Locations of the textual references can also be determined using the Chinese Text Project website: http://ctext.org/tools/concordance. My thanks to Chris Fraser for numerous suggestions on parsing the original text. Any infelicities are my own.
} 
Other stories include further details about the accumulation of skill and how it figures in satisfying way of life. In one such story, Kongzi runs into a hunchback catching cicadas with amazing dexterity. Kongzi inquires about his skills. The cicada catcher obliges, describing how he hones and sharpens his focus by balancing round pellets on top of one another. "If I can balance two without dropping them, l'll lose a few cicadas; if I can balance three, l'll miss just one in ten; if I can balance five, it will be like gathering them off the ground" (19/50/13-14). He then describes his heightened state of concentration while catching cicada:

"I settle my body like a tree stump, I hold my arm like the branch of a withered tree. Though heaven and earth are vast, though it contains a multitude of things, I am only aware of cicada wings. I don't wander or waver, and I would not trade cicada wings for any other thing. How could it be that l'd fail to succeed!" (19/50/14-15)

Kongzi later tells his disciples: "When the will is undivided, it congeals with the spirit" (19/50/16).

This latter term 'spirit' is a translation of shen 神, the source of a person's agency or vitality. It reappears in other discussions of skill in the Zhuangzi. In one such story, Kongzi tells his student Yan Hui of a time he encountered a ferryman handling a boat as though he were a spirit (shen 神). The ferryman claimed that the secret lay in forgetting what others cannot but bear in mind (i.e. the risk of drowning). He draws an analogy with high-stakes competitions.

When shooting [your arrow] for earthenware you're skilful; when shooting for fancy belt-buckles you're apprehensive; when shooting for gold you're discombobulated. Your skill is the same as ever, yet there's something that you come to be concerned withthis is attaching weight to what is outside you. Whoever gives weight to what is outside him is being clumsy within.' (19/50/22-23)

Elsewhere, we read of a woodworker named Qing who carved a bellstand so amazing, people thought it was made by a ghost or spirit. A Marquis, marveling at his skill, asks his secret. The woodworker claims to achieve heightened focus through fasting and forgetting. "After fasting three days, I no longer keep in mind congratulations and reward, honors and salary. After five days, I no longer keep in mind blame or praise, skill or clumsiness. After seven days, I am so intent that I forget that I have a body and four limbs." The passage continues:

'During this time my lord's court does not exist for me. My skill concentrates, outside distractions melt away, and only then do I go into the mountain forest and observe the nature of the wood. When I see one of perfect form-only then is my vision of the 
bellstand formed, and only then do I put my hands to it. Otherwise, l'll just give the whole thing up... What people took to be the workings of a spirit in the vessel-could this be it? $(19 / 52 / 5-8)$

Some have noted similarities between these accounts and the experience of 'flow', as popularized by Mihalyi Csikszentmihalyi (e.g. Barrett, 2011; Singh, 2014). Consider the following conditions that accompany experiences of flow:

- Perceived challenges, or opportunities for action, that stretch (neither over-matching nor underutilizing) existing skills; a sense that one is engaging challenges at a level appropriate to one's capacities

- Clear proximal goals and immediate feedback about the progress that is being made. (Nakamura and Csikszentmihalyi, 2014, p. 240)

There are obvious points of contact here with the skill stories in the Zhuangzi, which involve activities that are challenging yet not beyond the skills of the performer, with immediate goals internal to the activity itself. There are further parallels in the phenomenology of flow-type activities:

- Intense and focused concentration on the present moment.

- Merging of action and awareness.

- Loss of reflective self-consciousness (i.e., loss of awareness of oneself as a social actor)

- A sense of control; that one can in principle deal with the situation because one knows how to respond to whatever happens next.

- Distortion of temporal experience (typically, a sense that time has passed faster than normal).

- Experiencing the activity as intrinsically rewarding, such that the end goal is often a mere excuse for the process.

(Nakamura and Csikszentmihalyi, 2014, p. 240)

Many of these features of flow are noted explicitly in the stories above, while the rest are either consistent with them or can be inferred from them (though cf. Slingerland, 2000; Fraser, 2014).

I highlighted the use of the term shen (spirit / spirited) in the passages above. It is seldom noted, but significant, that in all the cases so far it is a term out-of-touch observers use to describe the manifestation of skill (whether in product, performance, or performer). Yet the performers themselves do not use this term, and thus it is difficult to know whether the observers' comments should be read as veridical - that is, reflecting the way the author sees 
these things (as truly spiritual achievements) —or as a reductio, reflecting the worthless perspective of the elitist.

The chief passage in support of the former interpretation is also the most famous skill story in the text. It involves a dialogue between a lord and his lowly cook.

Cook Ding was carving up an ox for Lord Wen-hui. Wherever his hand slapped, wherever his shoulders dipped, wherever his foot braced, wherever his knees pressed, the thwack! and thud! of flesh falling off and knife penetrating flesh was in perfect cadence, now in time with the Mulberry Forest Dance, now in tune with the Jing Shou Chorus. 'Wow! Excellent!' said Lord Wen-hui. 'That skill should attain such heights!' $(3 / 7 / 30-3 / 8 / 2)$

These opening lines depict the flow-like state of Cook Ding carving his ox, and the appearance of an elite (Lord Wen-hui) once again signals that he is meant to be a foil. The passage continues with the cook's response:

'What your servant loves is dao; I have advanced past skill. When I first began to carve oxen, I saw nothing but the ox. Three years more and I stopped seeing the ox as a whole. Nowadays, I encounter it with my spirit, and no longer look with my eyes. My overseeing knowledge ceases, and the spirit's impulses proceed. I rely on nature's layering, cleave along the main seams, follows the main cavities, and go by what is inherently so. A ligament or tendon I never touch, not to mention solid bone.

'A good cook changes his chopper once a year, because he cuts. A common cook changes it once a month, because he hacks. Now I have had this chopper for nineteen years, and have taken apart several thousand oxen, but the edge is as though it were fresh from the whetstone. The joints have spaces gaps, and the edge of the blade has no thickness. If you insert what has no thickness into a gap, then there's wide open spaces, and of course there is ample room to move the edge about. That's why after nineteen years the edge of my chopper is as though it were fresh from the whetstone.

'However, whenever I come to something knotty, I resign to the difficulty ahead. I proceed with caution and halt my gaze. My actions slow, my blade barely flicks and yet the whole thing crumbles to the ground. I stand, knife in hand, looking round proudly at the results, dawdling to enjoy the triumph until I'm quite satisfied. I then wipe the blade and put it away. ' 
'Excellent!' said Lord Wen-hui. 'Listening to the words of this cook, I have learned how to nurture life. ' $(3 / 8 / 4-11)$

Cook Ding's trance-like flow-states of engagement while carving oxen are described as going 'beyond skill', and indeed Lord Wen-hui is not only amazed at the cook's performance, but is even more impressed by his words. Lord Wen-hui hears the cook discuss his butchery and learns something about life and how to nurture it. Presumably, the secret to nurturing life involves analogous engagement with the world through one's spirit (a point that is echoed in the next chapter, In the World of Men, though within a political context).

The cook might thus be taken to represent something above and beyond skill. Edward Slingerland, for example, argues that we cannot understand expert skill per se to be the ultimate goal of any of the practices above. Skilled mastery in one domain is consistent with being an atrocious human being as a whole (e.g. abusive or malevolent to others). For Slingerland, this is unacceptable. Instead, we must understand such flow states as representing "a perfection of a unique and ultimate skill: the skill of becoming a fully realized human being and embodying the Way in the full range of one's actions". On this reading, the ideal "involved relating the individual to a larger normative cosmic order-as well as presenting an at least implicit picture of human nature as it relates to this order". Thus, this is "first and foremost a spiritual ideal... [with] roots in archaic Chinese religion" (Slingerland, 2007, p. 9 emphasis added).

Lee Yearley makes similar arguments. He reads into the text a special notion of drives called 'transcendent' drives, and he sees such drives depicted and celebrated throughout the text of the Zhuangzi.

Transcendent drives generate activities that exceed the normal capacities of the self and seem to arise from beyond it. They produce abilities that surpass normal abilities and transform normal actions... I find myself able to perform easily and well tasks that previously seemed to be far beyond my normal capabilities. Transcendent drives... allow powers such as the 神 shen, "daemonic"... to possess a person and therefore they help bring to a person the highest possible spiritual fulfillment. (Yearley, 1996, p. 154)

Given this latter spiritual dimension, Yearley maintains that skilled activity in the text "transcends what most people would identify as normal skillfulness" (164). ${ }^{2}$

Such religious approaches tend to inflate the wondrous qualities of the skills involved, and advert to extra variables (e.g. the spirit, the 'daemonic', or 'transcendent drives') in order to

\footnotetext{
${ }^{2}$ Notwithstanding the prevalence of such interpretations, it remains unclear whether heightened or perfected skill is really different in kind as opposed to mere degree. For discussion, see Wenzel (2003).
} 
explain this heightened gap between the ordinary and the extraordinary. But, as noted above, the fact that some of the activities seem rather ordinary (such as swimming, or catching cicadas - something children still do in China today) yet still engendering wonder and awe among the elite might instead be making light of just how divorced and alienated these elites are. Hans Georg Moeller and Paul J. D’Ambrosio (2017) see both sides at work. However, they believe the fact that the skilled protagonists routinely reject being extraordinary weighs in favor of a more deflationary reading.

The extreme waterfall diver at Lüliang, the nameless drunkard mastering the art of falling off carts unharmed, and Cook Ding, the symphonic slaughterer, are oddly exaggerated 'players,' partly surreal and partly comical, partly mundane and partly miraculous. They are larger than life and at the same time most average, wonderful, and ordinary. Their stupefying skills are accompanied by the utmost unpretentiousness. These paradoxical artists disown their arts.... Thus, both the artisans and their arts are de-idolized and 'normalized,' and a routine of a paradoxically common and contingent excellence that one may or may not engage in emerges. (Moeller and D'Ambrosio, 2017, pp. 183-184)

The Zhuangzi is not alone for containing noteworthy depictions of skill and mastery. Thinkers and texts we now associate with the Ruist (or Confucian) tradition also invoke examples of skill and expertise across a number of domains, including (and especially) skill at forging human cultural and societal institutions. Exemplars of these kinds are venerated by the Ru for both creating and perpetuating culture through acts of human artifice (wei 偽), for it is only through their faithful transmission that culture can persist and thrive, benefiting and beautifying humankind. In the classical text The Rites of Zhou (周禮), we find a typical way the Ru saw these things.

The knowledgeable fashion things; the skillful transmit and maintain these things through generations. They are called artisans. The affairs of the hundred artisans are all thus creations of the sages. Some smelt metal to make knives; some harden the earth to make implements; some build chariots to travel over hills; some build boats to travel over water. All of these are things that were created by the sages. (Puett, 2001, p. 77)

However, what is most striking from a contemporary perspective is the prevalence of a certain kind of expertise venerated by the Ru and Mohists alike. This is the idea of moral or ethical expertise. 


\section{Ethical Expertise}

The examples adduced above represent apt domains of expertise. As Christian Helmut Wenzel writes, the invocation of skill in these contexts is apt "because there is a specified range of objects, which corresponds to the specific craftsmanship, and because there are certain criteria of success that are available right from the start. Cook Ting [Ding] does not try to be a good swimmer, and the ferryman does not cut oxen" (Wenzel 119). By contrast, the idea that one might be an expert (or highly skilled) at ethics seems odd. What does ethical expertise consist of? How is it possible? The criteria themselves are subject to much dispute (should we focus on intent, character, or consequences?), and demonstrating ethical expertise seems problematic. If one were to skeptically interrogate the cicada catcher about whether he really has skill, he can just show the bounty of his hunt, for example. What could be the analogue in the ethical domain? Answering these questions would obviously take us far beyond the scope of this chapter. Nonetheless, some early Ruist texts had answers to these questions.

At a basic level, these texts maintained that one can be an expert at ethics because the core of ethics consists of adhering to and exemplifying norms of ritualized propriety (li 禮), a set of traditional protocols, ceremonies, rules of etiquette, and other formalized aspects of social interaction that, from their perspective, were honed and perfected by preceding generations of sagacious rulers and ministers, and passed down as a cultural inheritance that could then form the basis of an ethics curriculum. ${ }^{3}$ The li included detailed and formalized rites and ceremonies keyed to significant life events on one end of a spectrum, with etiquette, manners, and basic courtesy on the other. They were thought to constitute the wisdom of ancient sages of impeccable character, and were revered as holding the key to proper enculturation, humanization, and communication. (A nearby, if imperfect, analogue for modern Westerners might be the norms governing conduct of the nobility in Victorian England.) These norms-the li-would apply to most social situations, and could be analogically extended to apply to all facets of life (Sarkissian, 2014).

It is important to note just how demanding the li were, and how long the Ru thought it would take to gain mastery of them. In the Analects (a collection of sayings and anecdotes about Kongzi and his immediate circle of interlocutors), for example, Kongzi claims to have started diligent study and practice at the age of 15 , and only at the age of 70 had he internalizing these norms and honed his ethical sense such that his immediate inclinations were always correct (Analects 2.4). Xunzi (a 3rd century BCE Ru), takes up this line with vigor, and is at pains to note that skill or mastery at ethics does not consist of mere memorization of rules or

\footnotetext{
${ }^{3}$ The traditional 'Six Arts' (六㙯) of education included not only the rites (禮), but also music (樂), archery (射). charioteering (御), calligraphy (書), and mathematics (數). We focus on ritual, as it was considered most central.
} 
rote mimicry of others, but must also involve grace, dignity, and an ability to elicit from others (especially those less conversant in the ceremony) appropriate feelings and attitudes.

Nonetheless, they maintain that ethical expertise is amenable to the kind of sustained, iterative improvement accompanying other forms of skill acquisition noted above, provided one has proper guidance. Justin Tiwald (2012), for example, has explicated Xunzi's model of expertise by noting two kinds of ethical knowledge a student must master. The first is knowledge of general models ( $f a$ 法) of ethical behavior. Much of this will include knowledge of the li as well as paradigmatic instances of right actions, and can be fairly general at their level of description (e.g. one must not address one's parents in a disrespectful fashion). The second kind of knowledge concerns how to apply these models in one's own life. Both kinds of knowledge-though especially the second-require guidance by expert teachers or mentors (shi 師). "Ritual is that by which to correct your person. The teacher is that by which to correct your practice of ritual. If you are without ritual, then how will you correct your person? If you are without a teacher, how will you know that your practice of ritual is right?" (Hutton, 2014, p. 14)

Anyone on the streets can become a Yu [a sage king]. How do I mean this? I say: that by which Yu was Yu was because he was ren [humane], yi [right], lawful, and correct. Thus, ren, yi, lawfulness, and correctness have patterns that can be known and can be practiced. However, people on the streets all have the material for knowing ren, yi, lawfulness, and correctness, and they all have the equipment for practicing ren, yi, lawfulness, and correctness. Thus, it is clear that they can become a Yu. (Hutton, 2014, p. 254)

Teachers help the student to match these models of ethical behavior to particular circumstances. Through such guidance, the student is able to gradually deepen their understanding of the ethical life. They will come to see, for example, how the various models (the first kind of knowledge) hang together and form a coherent set, and how they instantiate a wider system of goods and values. ${ }^{4}$

Through such direct, personal, and experiential forms of learning, students can begin to note for themselves how various locutions or details of their comportment can signal respect, care, and consideration of others, and how their own conduct impacts and moves them. By noting their successes and failures, those pursuing ethical mastery can eventually achieve a kind of 'deliberative autonomy' whereby they no longer require the aid of teachers or mentors

\footnotetext{
${ }^{4}$ One might wonder which of the numerous kings and heroes of antiquity to take as models. Choosing from among them would likely require expertise of its own. Amy Olberding (2012), for example, has argued that the nature of Kongzi's expertise lay in his ability to identify true exemplars and articulate the coherence among them by developing by developing a shared vocabulary.
} 
to correct their practices, and can engage in reflection and self-correction in an effective manner themselves. Some have suggested that this overall picture of ethical knowledge or expertise cannot be readily assimilated into categories such as 'knowing that' or even 'knowing how'. Instead, some early Ruist texts contain a distinctive notion which we might understand as knowing to, as in knowing to act in the moment (Lai, 2012; Hetherington and Lai, 2015). This too can be understood as a kind of expert skill. Others, such as Aaron Stalnaker, have argued that particular virtues in these classical Ruist texts should be thought of as partially constituted by mastery of a certain set of skills (Stalnaker, 2010). Still others have characterized this kind of skill as driven by intuitive inclinations cultivated through the sustained accumulation of a broad range of concrete experiences. Borrowing from Antonio Damasio's somatic marker hypothesis (Damasio, 2006), the current author has argued that expertise involves the honing of spontaneous inclination. According to Damasio, as one encounters particular situation types, one's mind is full of a diverse repertoire of latent inclinations attuned to the situation at hand via past experience. Each of these have a qualitative feel or valence (e.g. "that might be good," "this might be bad," etc.), working to limit the possible actions and outcomes to pursue. Sarkissian argues that this "fine-tunes and accelerates the decision-making process; at the limit, the correct course of action would come to mind immediately, with compelling emotional valence."

In completely novel situations, we may be at a loss for an appropriate response, leaving us immobile. Similarly, where social configurations trigger overlapping schemes associated with multiple markers, we may be perplexed and unsure how to react. This can occur, for example, in situations where we find individuals playing roles we are not accustomed to seeing them play or when we encounter individuals acting according to situational norms that conflict with our own. However, familiarity with a broad range of emotions, facilitated through exposure to literature, art, and social rituals, will allow one to perceive values in a wide range of scenarios, thus improving the likelihood of responding appropriately in any particular situation. (Sarkissian, 2010a, p. 7)

When ethical skill advances sufficiently, and as one becomes recognized as trustworthy and reliable, the Ru maintain that one cultivates a felt presence or personal power (de 德), a kind of gravitas or charisma that accompanies one's behavior and judgments, lending one authority and rendering others cooperative and agreeable-disposed to defer to one's ethical expertise (Nivison, 2002; Sarkissian, 2010b, 2017; Barnwell, 2013).

Thus far, the account of ethical expertise has focused largely on two early thinkers in the Ru school—namely, Kongzi and Xunzi. The 4th century BCE thinker Mengzi (better known to Westerners as Mencius), shares much in common with them. However, his model of expertise departs from theirs in distinct ways. A key passage occurs in Mengzi 6A7. There, Mengzi infers 
that our sensory modalities each have built-in preferences, explaining why expert musicians can produce orchestrations that delight any who hear it, or why expert cooks can produce dishes that delight anyone who taste them. By analogy, the human heart (xin 心), the cite of cognition, affect, and volition (thus also translated as heart/mind) must have built-in preferences too. Mengzi claims that the sage kings venerated by the Ru (such as Yao and Shun) discovered what these were, and promulgated ethical standards of order (li 理) and rightness (yi 義) to others, who similarly delighted in them. In an extended discussion of this passage, Hutton claims that, for Mengzi, "the sages' moral knowledge consists in a developed ethical 'taste,' much as Yi Ya's culinary knowledge and Music Master Kuang's musical knowledge consist in a kind of cultivated expertise" (Hutton, 2002, p. 172). On this view, "the sages are above all connoisseurs of the human heart. Their focus is inward, and what their special knowledge concerns is not so much human behavior in general and the way the world at large works per se, but rather what sorts of behaviors and states of affairs are most pleasing to the heart, given its innate preferences" (ibid., 174).

However, as Dobin Choi (2018) points out, if we take the analogy with Yi Ya and Shi Kuang seriously, it is more likely that Mengzi meant to analogize the sages' morally admirable behavior and personal example to Yi Ya's dishes and Music Master Kuang's compositions. The sages are not merely connoisseurs in the sense of being able to perceive what is morally good; rather, they enact moral goodness through their own persons and the virtues and values they exemplify. Upon contemplating the sages' behavior, other people delight in it, just as they do masterful dishes and compositions. This suggests a similar structure to all the analogies above: there is an expert who creates or uncovers something that elicits a sentiment of approval among the people, showing that people have innate preferences; moreover, the sentiment of approval elicited by the people itself instantiates or affirms the excellence of the expert creation.

The Ru were not alone in venerating cultural heroes of the past and holding them up as models of expertise to emulate. This was also the orientation of the Mohists, a rival school of thinkers similarly engaged in the project of social and political reform. They disagreed with the $\mathrm{Ru}$ on which figures were worthy of emulation and for what reasons, and their conception of expertise thus adverted to a distinct set of concerns. The Mohists rejected the idea that traditional customs, mores, and ceremonies ought to be taken as reliable guides to what is right. When they look to the sage kings as models, they do not include the sorts of cultural achievements and traditional practices that comprised the Ru curriculum and generally established as customary among the elite (such as lavish funerals for one's deceased parents). Rather, they argued that one must have an objective standard to define which customs are beneficial and ought to be perpetuated, and which are detrimental and ought to be abandoned or reformed. Importantly, they argued that the sage rules of antiquity ought to be followed 
because they modeled themselves on just such an objective standards—namely Tian 天 or Heaven, a supernatural agent of impartial concern.

It is said that there is no standard like Heaven. Heaven is broad and unselfish in its actions, and is generous in its bestowing without considering itself virtuous. Its radiance is enduring and does not decay. Therefore, the sage kings took it as the standard... Undoubtedly what Heaven desires is that there be mutual love and mutual benefit among people. (Johnston, 2009, p. 27)

If this is so Heaven's intentions might be modeled by people directly. And such modeling is depicted as a kind of skill, analogous to those needed in crafts.

The hundred craftsmen make what is square with a square, make what is round with compasses, use a straight edge to establish what is straight, determine the horizontal with a water level, and the vertical with a plumb line. Whether skilled or unskilled, craftsmen all take these five things as standards. Skilled craftsmen are able to comply with these standards whilst unskilled craftsmen, even if they are unable to comply with them, will still surpass themselves if they follow them in their work. Thus the hundred craftsmen all have standards as a basis for their work. Nowadays, the greatest [achievement] is to bring order to the world and the next greatest is to bring order to a large country, but to attempt these things without reliance on standards is to compare unfavourably in wisdom with the hundred craftsmen. (ibid., 25)

Given this general sketch, we can now outline what ethical expertise consists of for the Mohists: an ability (that is, a capability or disposition) to discriminate and apply correct models or paradigms to current circumstances, with these models being the precedents of sage kings guided by, and conforming to, the will of Heaven. In an upshot, expert ethical action should promote the will of Heaven, which is to secure material benefit and care for all. According to Chad Hansen, the Mohists advert to this objective standard, yet remain dependent on teachers to guide one's application of the standard. The Mohists

... take for granted that things really are similar and different. On the basis of objective similarity and difference, we make socially approved distinctions. Once we have achieved virtuosity or competence in discriminating, we assume that our use is correct. Thus it is that Mozi cannot dispense with Confucius' teacher-student method of transmission even though he wants a more objective, realistic content. Our basic 
linguistic skill in making distinctions requires a string of teacher-student embodiments. (Hansen, 1992, p. 104)

Similarly, Chris Fraser argues that what drives ethical action for the Mohists "is mainly ability or know-how (zhi 知), which is largely the result of skill training. Moral education and cultivation thus are processes similar in important respects to skill development" (Fraser, 2016, p. 23).

Action is regarded as a skilled response to things or situations. It is triggered by the agent's distinguishing a thing or situation as being of a certain kind and thus invoking a relevant, normatively appropriate response. Instead of tying agency to our capacity for reasoning, this model bases it primarily on our capacity to acquire and exercise skills and virtues. (ibid., 76) ${ }^{5}$

The Mohists advocate reforming governing structures and hierarchies so as to promote those who are just so skilled, who they deem the worthy (xian 賢). Good government requires this kind of ethical expertise, which in turn demands a degree of individual autonomy, or the ability to make such classifications oneself independent of one's superiors (Brindley, 2007). In other words, making correct ethical judgments is a form of skill, and ethical failure results from a lack of such skill.

While diverging in certain important aspects, both the Ru and the Mohist conceptions of ethical expertise presuppose and rely upon the skilled matching of previously learned models to particular cases. Fraser (2009, p. 76) argues that we can take this general model as paradigmatic of classical conceptions of agency.

\section{Concluding Thoughts / Future Research}

Several classical thinkers in the Chinese tradition thought that central agentic notions such as deliberating, choosing, and acting consisted of a kind of analogical reasoning. When one is deciding what to do or judging right from wrong, one analogizes the current case to a rehearsed set of models or prior examples that comprised one's basic education. Through this process, one sorts objects, actions, or entire states of affairs as falling under one classification or other. Prior learning provides one with response patterns to suit these various classifications.

\footnotetext{
${ }^{5}$ Fraser argues that Xunzi, discussed previously, builds on the Mohist model by further emphasizing the importance of teachers and mentors in learning how to properly discriminate and apply models (Fraser, 2016, p. 57). In chapter 8 of his received text ("The Achievements of the $R u^{\prime \prime}$ ), Xunzi claims that what distinguishes the great person from the petty person is precisely this ability to properly discriminate objects and categorize them correctly.
} 
To use an example, coming upon an instance where one might deem a person 'upright' (zheng 正) would require a skill to draw analogies between aspects of a person's conduct, reputation, etc., and a past paradigm of 'uprightness'. If the analogies are sufficiently strong, this would trigger relevant attitudes (e.g. admiration or deference) automatically. Judging the strength of analogy may require careful reasoning. Yet with a suitably rich experiential base from which to draw, implicit or explicit comparisons become more and more finely attuned. Over time, this process becomes less demanding and more spontaneous, and one's immediate inclinations to action align with normatively sanctioned responses. The crucial thing for present purposes is that this is a task that one can hone over time, gaining skill and mastery through incessant practice. The current author (Sarkissian, 2010a) has suggested a cognitive model that might help to explicate the mechanisms underwriting such a practice. Further research can help to develop and refine this general picture. If true, it suggests that various forms or skill and expertise rest upon shared assumptions about normal, healthy forms of agency.

Put another way, the depictions of skill and expertise above might all be underwritten by a shared capacity for pattern-recognition. The cook in the Zhuangzi story understands the natural patterns in the ox so as to effectively carve it up without dulling his blade; the skillful ritual expert must understand the patterns of emotional reaction and response in his audience so as to properly execute the rite; and the perspicacious student must come to learn how certain small tokens of behavior or small turns of event routinely unfold and resonate with other phenomena. Future work might examine more carefully the connections between metaphysical notions such as patterning on the one hand, and epistemological capacities such as recognizing and analogizing on the other. ${ }^{6}$

\section{References}

Barnwell, S. A. (2013) 'The evolution of the concept of de 德 in early China', Sino-Platonic Papers, 235.

Barrett, N. F. (2011) 'Wuwei and Flow: Comparative Reflections on Spirituality, Transcendence, and Skill in the Zhuangzi', Philosophy East \& West. University of Hawai'i Press, 61(4), pp. 679706.

Brindley, E. (2007) 'Human agency and the ideal of shang tong (upward conformity) in early Mohist writings', Journal of Chinese Philosophy. Blackwell Publishing Inc, 34(3), pp. 409-425.

\footnotetext{
${ }^{6}$ My thanks to Chris Fraser, Jing Hu, and David Wong for comments on previous drafts.
} 
Choi, D. (2018) 'Moral Artisanship in Mengzi 6A7', Dao, 17(3), pp. 331-348.

Damasio, A. R. (2006) Descartes' Error. New York: Random House.

Fraser, C. (2009) 'Action and agency in early Chinese thought', 中國哲學與文化. Guangxi Shi Fan Da Xue Chu Ban She (廣西師範大學出版社)., 5, pp. 217-239.

Fraser, C. (2014) 'Heart-Fasting, Forgetting, and Using the Heart Like a Mirror: Applied Emptiness in the Zhuangzi', in Liu, J. and Berger, D. L. (eds) Conceptions of Nothingness in Asian Philosophy. New York: Routledge, pp. 197-212.

Fraser, C. (2016) The Philosophy of the Mòž: The First Consequentialists. Columbia University Press.

Graham, A. C. (2001) Chuang Tzu: The Inner Chapters. Indianapolis: Hackett Publishing. Hansen, C. (1992) A Daoist Theory of Chinese Thought: A Philosophical Interpretation. New York: Oxford University Press.

Hetherington, S. and Lai, K. L. (2015) 'Knowing-How and Knowing-To', in Bruya, B. (ed.) The Philosophical Challenge from China. Cambridge: MIT Press, p. 279-301.

Hutton, E. L. (2002) 'Moral connoisseurship in Mengzi', in Liu, X. and Ivanhoe, P. J. (eds) Essays in the Moral Philosophy of Mengzi. Indianapolis: Hackett Publishing, pp. 163-186.

Hutton, E. L. (2014) Xunzi: The Complete Text. Princeton: Princeton University Press.

Johnston, I. (2009) The Mozi: A Complete Translation. Hong Kong: Chinese University Press.

Lai, K. L. (2012) 'Knowing to act in the moment: examples from Confucius' Analects', Asian Philosophy. Taylor \&\& Francis, 22(4), pp. 347-364.

Moeller, H.-G. and D'Ambrosio, P. J. (2017) Genuine Pretending: On the Philosophy of the Zhuangzi. Columbia University Press.

Møllgaard, E. (2007) An Introduction to Daoist Thought: Action, Language, and Ethics in Zhuangzi. London: Routledge.

Nakamura, J. and Csikszentmihalyi, M. (2014) 'The concept of flow', in Flow and the Foundations of Positive Psychology. Springer, Dordrecht, pp. 239-263.

Nivison, D. (2002) 'De (te): Virtue or power', in Cua, A. S. (ed.) Encyclopedia of Chinese Philosophy. London: Routledge, pp. 234-237. 
Olberding, A. (2012) Moral Exemplars in the Analects: The Good Person is That. New York: Routledge.

Puett, M. (2001) The Ambivalence of Creation: Debates Concerning Innovation and Artifice in Early China. Stanford: Stanford University Press.

Sarkissian, H. (2010a) 'Confucius and the effortless life of virtue', History of Philosophy Quarterly, 27(1), pp. 1-16.

Sarkissian, H. (2010b) 'Minor tweaks, major payoffs: The problems and promise of situationism in moral philosophy', Philosopher's Imprint. Citeseer, 10(9), pp. 1-15.

Sarkissian, H. (2014) 'Ritual and rightness in the Analects', in Olberding, A. (ed.) Dao Companion to the Analects. Springer Netherlands (Dao Companions to Chinese Philosophy, 4), pp. 95-116.

Sarkissian, H. (2017) 'Situationism, Manipulation, and Objective Self-Awareness', Ethical theory and moral practice: an international forum. Springer Netherlands, 20(3), pp. 489-503.

Singh, D. (2014) 'Zhuangzi, Wuwei, and the Necessity of Living Naturally: A Reply to Xunzi's Objection', Asian Philosophy. Routledge, 24(3), pp. 212-226.

Slingerland, E. (2000) 'Effortless action: The Chinese spiritual ideal of wu-wei', Journal of the American Academy of Religion. American Academy of Religion. Oxford University Press, 68(2), pp. 293-327.

Slingerland, E. (2007) Effortless Action: Wu-wei as Conceptual Metaphor and Spiritual Ideal in Early China. Oxford University Press, USA.

Stalnaker, A. (2010) 'Virtue as mastery in early Confucianism', The Journal of religious ethics. Wiley Online Library, 38(3), pp. 404-428.

Tiwald, J. (2012) 'Xunzi on moral expertise', Dao. Springer Netherlands, 11(3), pp. 275-293.

Wenzel, C. H. (2003) 'Ethics and Zhuangzi: Awareness, freedom, and autonomy', Journal of Chinese philosophy. Wiley Online Library, 30(1), pp. 115-126.

Yearley, L. H. (1996) 'Zhuangzi's understanding of skillfulness and the ultimate spiritual state', in Ivanhoe, P. J. and Kjellberg, P. (eds) Essays on Skepticism, Relativism, and Ethics in the Zhuangzi. Albany: State University of New York Press, pp. 152-182.

Ziporyn, B. (2009) Zhuangzi: The Essential Writings with Selections from Traditional 
Commentaries. Indianapolis: Hackett Publishing. 